\title{
Pedagogical Conditions for the Development of Self-Educational Competence of Future Specialists in the Study of Professional Subjects
}

\author{
Hanna P. Byhar ${ }^{1}$, Valentyna H. Zvozdetska ${ }^{2}$, Inna S. Prokop ${ }^{1}$, Iryna I. Pits ${ }^{1} \&$ Oksana Ye. Hordiichuk $^{1}$ \\ ${ }^{1}$ Department of Pedagogy and Methods of Primary Education, Faculty of Pedagogy, Psychology and Social Work, \\ Yuriy Fedkovych Chernivtsi National University, Chernivtsi, Ukraine \\ ${ }^{2}$ Department of Pedagogy and Social Work, Faculty of Pedagogy, Psychology and Social Work, Yuriy Fedkovych \\ Chernivtsi National Univetsity, Chernivtsi, Ukraine
}

Correspondence: Hanna P. Byhar, Yuriy Fedkovych Chernivtsi National University, 2 Kotsyubynsky str., Chernivtsi, 58012, Ukraine.

Received: June 10, 2020

Accepted: August 3, 2020

Online Published: August 7, 2020

doi:10.5430/ijhe.v9n7p257

URL: https://doi.org/10.5430/ijhe.v9n7p257

\begin{abstract}
The content of the categories "self-education", "self-educational competence" is analysed. The need for the development of self-educational competence of future specialists in the process of studying professional subjects is actualized. The pedagogical conditions for the formation of self-educational competence of future specialists in the study of professional subjects are determined. Such factors include: motivational and value attitude of future specialists to independent learning and cognitive activities in the process of professional training; ensuring the relationship of all areas of professional training of future specialists (theoretical, methodological, practical), which involves the formation of self-educational competence; development and implementation of educational and methodological support for the development of self-educational competence of students; the use of interactive technologies in teaching professional subjects to build educational dialogue. An experimental verification of the effectiveness of implementation of certain pedagogical conditions. For this purpose, a pedagogical experiment was organized. The conclusion that students of control and experimental groups have significant differences due not to random factors, but to a certain natural reason - conducting research and experimental work on the implementation of pedagogical conditions for the development of self-educational competence of future specialists in the study of professional subjects. Statistical analysis of indicators of transition of students to a higher level of self-educational competence shows that the process of formation of self-educational competence in students of the experimental group is more effective than in students of the control one.
\end{abstract}

Keywords: self-educational competence, self-organization, students, self-education, pedagogical conditions, professional subjects, future specialists

\section{Introduction}

Improving the system of higher education is one of the main goals of educational policy of Ukraine. In the modern conditions, a huge role in training specialists who are able to work effectively in their professional field and thus ensure the competitiveness of our country in the world is assigned to higher educational institutions (HEIs).

The need for the formation of self-educational competence of university students is due to both external in relation to the field of education (economic, socio-cultural) and internal (professional and pedagogical) factors. The analysis of educational practice showed that a significant part of HEI graduates experience difficulties in organizing and implementing self-education because of the lack of appropriate training.

The Education Development Concept 2020 sets the higher education system the task of training specialists in the priority areas of modernization and technological development of Ukraine's economy. Currently, the paradigm of education is changing and the role of self-educational activities is growing, so an important component of the professional competence of a graduate is self-educational competence (Sagitova, 2011).

It should be noted that self-educational competence becomes especially relevant in the age of global informatization in almost all areas of professional activity. Its role in professional activity becomes decisive for the professional growth of a specialist (Carlson, 2018). The studies of a number of modern researchers deal with identification of the role of self-educational competence in solving professional problems (Adaryukova, 2017). 
Let us note that the basic concepts for "self-educational competence" are the concepts of "self-education" and "competence" (Shkabarina, 2016). These concepts are characterized by different authors from different points of view. Let us consider the concept of "self-education" as a complex concept consisting of two parts: "self" and "education" (Kolomiets, 2018). "Education", in turn, has a double meaning: "contains an image" and "creating own image", where the image is "the result of the reconstruction of the object in the human mind" (Gura \& Lutseva, 2016). Thus, education can be explained as a cognitive activity of the subject, aimed at creating his/her own vision of objects and phenomena of the real world (Adam, 2008; Adubra, 2014). The element of "self" speaks of the personal nature of self-education, i.e. "education" of oneself as such, where the main role is played by the personal efforts of an individual.

Self-education is a free and at the same time quite complex part of educational activity. This is due primarily to the fact that self-education is based on the reflections of future specialists, awareness of their own resources, achieving effective personal and professional growth.

An analysis of the Ukrainian-language version of Wikipedia has shown that the free online encyclopaedia contains insufficient materials on students' self-education. There is only incomplete information about the family concept of

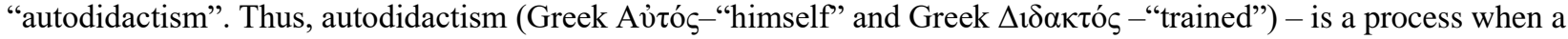
person independently obtains a high level of education outside any educational institution, without teacher's help (Levy, 2016). This understanding is close to our position, due to the emphasis on high independence in getting education in the absence of an educational institution. In our opinion, this is the connection between the concepts of "self-education" and "continuing education". Continuing education, as a process of self-creation, that covers the entire life of man (Stavitsky, 2013; Tregubova, 2013), performs the same functions as self-education:

- compensatory (filling gaps in basic education);

- adaptive (operational training and retraining in a changing production and social situation);

- developing (meeting the spiritual needs of an individual, the needs of creative growth).

Let us note that the concept of "self-educational competence" was used in education in the 70's in America (University of Massachusetts) in the context of "competence", which was then applied to the theory of language and transformational grammar (Snam, Rusiman, Gan \& Arbin, 2018).

Over time, self-educational competence changes, both from a subjective and an objective point of view (Sagitova, 2010; Ualiyeva, Murzalinova, \& Kucher, 2016). On the one hand, there are new sources of information, scientific schools, tools and software for working with information, while on the other hand, a person himself, his requests, desires, values change (Ahrens, Purvinis, Zashcherinskaya, \& Andreeva, 2016; Sokolova, 2013; Bilousova \& Kiselyova, 2012). That is why, in our opinion, it is necessary to form the focus on the use of self-educational competence throughout life in future specialists in the study of professional subjects. In our opinion, self-educational competence has a meta-subject nature that does not depend on the profession, but also contains a variable part, depending on age, education, personal qualities and passions (Batista \& Elliot, 2014). Our research deals with the development of self-educational competence of future specialists in the study of professional subjects while studying in the HEIs, thus determining the part of the variable component that is characteristic of students.

Analysis of the literature (Sakhieva, 2015; Shazia \& Muhammad, 2015; Maravilhas, 2015, etc.) on the research problem showed that there is no consensus in determining the nature and structure of students' self-educational competence. Sakhieva (2015) defines students' self-educational competence through its manifestation in the ability to find sense in the field of their education, setting goals and objectives of self-educational activities, orientation in the information-professional space, developing their own system of self-organized cognitive activity, choosing and effectively using modern information support of self-education. The author considers the development of students' self-educational competence by mastering their key, in her opinion, competencies: moral and semantic, communicative, basic, computer, methodological.

According to Adaryukova (2017), a student's self-educational competence is an integrative personal property, which is provided by an emotional and value attitude to self-development and self-educational activity, a system of knowledge about planning and realization of self-educational activity, about ways of self-education; subject-personal experience of productive solution of problems of development, development and realization of models of preparation of students for self-educational activity; subjective-personality experience of productive solution of problems of development; readiness for continuous self-development of professional qualities, self-improvement, self-education in the field of future profession (Adaryukova, 2017). The author distinguishes motivational-value, cognitive, operational-activity and reflexive components in the structure of self-educational competence. We support the opinion of Adaryukova 
(2017) that the student's self-educational competence is a criterion for the quality of his training, is an indicator of professional readiness and a factor of social competitiveness of a future graduate.

In the study of Melnychuk (2018), self-educational competence of students is considered as an integral part of general cultural and professional competence, which is the main indicator of personal development and includes experience of independent trials and achievements in self-educational activities, experience in developing one's own individual learning system, transition from copying patterns of self-education to developing one's own model, inclusion of self-education in the way of life. This approach, in our opinion, reflects the stages of the process of forming self-educational competence of future specialists in the study of professional subjects, which involves the gradual progress of students from episodic self-educational tests to a stable system of self-educational activities.

Within the study, self-educational competence is understood as a complex personality-significant characteristic, which is expressed in a set of motivational, cognitive, activity and communicative components and takes into account the personal attitude to the process of independent acquisition of knowledge, skills and abilities. The mentioned characteristic is revealed in readiness to use self-educational knowledge, abilities, skills in a certain subject area, and provides efficiency of professional education of an individual.

Given the above connection of self-educational competence with universal learning activities, we have identified the following areas of the development of self-educational competence of future specialists in the study of professional subjects:

- self-educational motivation - motivation to work in the field of self-education in the educational process of HEIs;

- self-educational knowledge - knowledge of the basic ways of acquiring knowledge in the conditions of informatization of society;

- self-educational activity - independent activity associated with raising the level of education, gaining new knowledge, improving professional skills and abilities;

- self-educational communication - communicative actions in the process of self-education and reflection of the results of the self-educational process as communication with oneself. The outlined directions of formation of the studied phenomenon require the selection of effective pedagogical conditions that would promote the development of each component of self-educational competence of future specialists. In a general sense, pedagogical conditions are a set of organizational factors that create a certain influence on a particular phenomenon of pedagogical reality (Ualiyeva et al., 2016; Vostiyanova, 2017).

There is currently a popular approach in pedagogical science (Barbosa-Chacón \& Castañeda-Peña, 2017; Estriegana, Medina-Merodio, \& Barchino, 2019), according to which a certain pedagogical condition is directed to the development of each component of the studied phenomenon. We will continue to follow this logic. To test the effectiveness of the distinguished pedagogical conditions, an experimental study was organized using a number of cognitive methods.

\section{Materials and Methods}

One of the key methods of scientific research was a pedagogical experiment, which was conducted in several stages. The pedagogical experiment, at all its stages, involved 87 students from different faculties of the university (History, Psychology and Pedagogy, Physics and Mathematics, Faculty of Social Management), as well as 8 teachers of HEIs, who participated in research and experimental work.

The main purpose of research and experimental work was to experimentally test the effectiveness of a set of pedagogical conditions for the development of self-educational competence of future specialists in the study of professional subjects. Research and experimental work was carried out in three stages:

- the formative stage was aimed at: analysis of philosophical, psychological and pedagogical literature, as well as regulatory documentation on the researched problem; conducting a formative assessment to identify the real state of the problem; adjustment of pedagogical conditions, indicators, levels and criteria of formation of self-educational competence of future specialists;

- the formative stage provided generalization of materials of the first stage of experiment, active influence on the investigated object in the course of formative experiment concerning verification of efficiency of pedagogical conditions of the development of self-educational competence of future specialists;

- final stage - processing and generalization of research results was carried out, the main conclusions were drawn, research results were prepared; prospects for further research were determined. 
The content of the stages of the pedagogical experiment, the objectives to be achieved, as well as the methods used at each stage of the pedagogical experiment are represented in Table 1.

Table 1. Stages, tasks and methods of pedagogical experiment

\begin{tabular}{|c|c|c|}
\hline Stages & Objectives & Methods \\
\hline The first stage & $\begin{array}{l}\text { - identify the initial level of self-educational competence } \\
\text { of future specialists; } \\
\text { - determine the pedagogical conditions for the } \\
\text { development of self-educational competence of future } \\
\text { specialists in the study of professional subjects; } \\
\text { - identify indicators, levels, criteria for the formation of } \\
\text { self-educational competence of future specialists. }\end{array}$ & $\begin{array}{l}\text { - Analysis of philosophical, } \\
\text { psychological and pedagogical } \\
\text { literature, as well as regulatory } \\
\text { documentation; } \\
\text { - questionnaires; } \\
\text { - conversations; } \\
\text { - pedagogical observation; } \\
\text { - testing; } \\
\text { - ranking. }\end{array}$ \\
\hline $\begin{array}{l}\text { The } \\
\text { stage }\end{array}$ & $\begin{array}{l}\text { - summarize the materials of the first stage of the } \\
\text { experiment; } \\
\text { - develop and test research methods; } \\
\text { - test experimentally the effectiveness of the selected } \\
\text { pedagogical conditions for the development of } \\
\text { self-educational competence of future specialists in the } \\
\text { study of professional subjects. }\end{array}$ & $\begin{array}{l}\text { - statistical and mathematical methods } \\
\text { of primary processing of results; } \\
\text { - informational and explanatory; } \\
\text { - problem-based learning: } \\
\text { - projects; } \\
\text { - methods of diagnosing the level of } \\
\text { the development of self-educational } \\
\text { competence of future specialists }\end{array}$ \\
\hline The third stage & $\begin{array}{l}\text { - identify the dynamics of the level of development of } \\
\text { self-educational competence of future specialists; } \\
\text { - prepare the results of the experiment; } \\
\text { - draw conclusions; } \\
\text { - determine the prospects for further research. }\end{array}$ & $\begin{array}{l}\text { - theoretical analysis, synthesis, } \\
\text { generalization and systematization of } \\
\text { material; } \\
\text { - methods of visual presentation of } \\
\text { research results; } \\
\text { - statistical and mathematical methods } \\
\text { of processing the results of the } \\
\text { experiment. }\end{array}$ \\
\hline
\end{tabular}

Let us note that in the process of diagnostic research, we took into account the multicomponent structure of self-educational competence of future specialists represented by a set of motivational, cognitive, activity and communicative components. On this basis, four levels of the development of each component of the studied competence were identified:

- reproductive-empirical (low) (A);

- productive activity (below average) (B);

- search and logical (above average) (C);

- design and research (high) (D).

\section{Results}

Based on the analysis of the data of the diagnostic stage of the study, the pedagogical conditions for the development of self-educational competence of future specialists in the study of professional subjects were determined. Such factors include: motivational and value attitude of future specialists to independent educational and cognitive activities in the process of professional training; ensuring the relationship of all areas of professional training of future specialists (theoretical, methodological, practical), which involves the formation of self-educational competence; development and implementation of educational and methodological support for the development of self-educational competence of students; the use of interactive technologies in teaching professional subjects to build educational dialogue. 
The first pedagogical condition is the motivational and value attitude of future specialists to independent educational and cognitive activities in the process of professional training. The implementation of this pedagogical condition is seen in the organization of annual exhibitions, which demonstrate the achievements, the results of independent educational and cognitive activities of students; organization and holding of competitions of professional skill among future specialists of one specialization.

Sustainable motivational and value attitude of students to independent educational and cognitive activities in the process of professional training is characterized by the desire to acquire knowledge and accumulate professional experience, the desire to engage in professional activities in the future, thrive for self-development, improve the skills, be inquisitive, and have such motives as "how to successfully continue professional training in HEI", "how to ensure the success of future professional activities", etc.

The second pedagogical condition is the interconnection of all areas of professional training of future specialists (theoretical, methodological, practical), which involves the development of self-educational competence.

Theoretical training of future specialists in accordance with the requirements of State Educational Standards includes joint work of students and teachers who organize classes in all professional subjects included in the curriculum, aimed at acquiring knowledge of the principles, methods, ways, forms of professional activity. Each course has its own opportunities in the theoretical training of students for the organization of independent cognitive activity.

Practical training of students provides their involvement in educational and independent cognitive activities, during which students get equipped with professional skills and abilities, as well as specific skills of self-educational activities. Practical training is carried out in seminars, practical and laboratory classes, during pedagogical practice, writing term and graduation papers.

The third pedagogical condition is the development and implementation of educational and methodological support for the development of self-educational competence of students. A complex of educational and methodical support included:

- educational and methodical complexes of professional subjects;

- technological maps of professional subjects;

- reference schemes and tables on professional subjects;

- multimedia presentations on professional subjects;

Educational and methodical complexes of professional disciplines are the basis of organizational and methodological support of the educational and creative process and an important factor in strengthening and developing the information space and resource provision of all links and branches of continuing education.

Educational and methodical complexes of professional subjects were aimed at achieving the following objectives:

- determining the place and role of the subject in the educational program of a particular speciality;

- implementation of interdisciplinary logical connections of the educational program;

- distribution of study time by topics and types of classes;

- organization of independent work of students in curricular and extracurricular time;

- activation of cognitive and creative activity of students;

- ensuring the relationship of educational and research processes.

The fourth pedagogical condition of our scientific research is the use of interactive technologies in teaching professional subjects to build educational dialogue. In this case, there is the following dependence according to the features of the activity of the teacher and students depending on the degree of interactivity of teaching aids: the higher the level of interactivity of teaching aids, the higher self-educational activity of students, the lower the labour intensity of the teacher's activity and the greater variety of applications of interactive technologies.

In such conditions, the teacher does not playusual role of a lecturer-informant, but rather the role of a supervising consultant, who uses interactive technologies to build students' self-educational competence. In particular, we are talking about design methods. Thus, working on a project requires students to have a fairly high degree of independence, coordination of their actions, active research, performance and communicative interaction. In these conditions, students learn to work with scientific literature, acquire skills of critical selection and analysis of the necessary information that as a whole promotes formation of self-educational competence. The outlined pedagogical 
conditions were realized comprehensively during the formative stage of the study and contributed to the formation of all components of self-educational competence of future specialists.

\section{Discussion}

The pedagogical experiment was conducted during the 2017/18 and 2018/19 academic years. The study involved 87 students from four faculties of the leading free educational institutions of Ukraine: Faculty of Physics and Mathematics, Faculty of Psychology and Pedagogy, Faculty of History, Faculty of Social Management, 26 of them were included in the control group (CG) and 61 - in the experimental group (EG).

The percentile was used to standardize the initial results of diagnostic tests and questionnaires, as it can be used to standardize both normally distributed scores and data with abnormal distribution (Nigmatullina \& Boltakova, 2014; Oleynikova, 2009).

Percentile is the percentage of individuals in the standardization sample whose initial result is below the initial indicator (Titkova, 2002). After calculating the percentiles for each component of self-educational competence, a table of standardization was made. The fiftieth percentile (P50) corresponds to the central trend. Percentages above 50 are represented by above-average values, and those below 50 are relatively low, the $25^{\text {th }}$ and $75^{\text {th }}$ percentiles are also known as the $1^{\text {st }}$ and $3^{\text {rd }}$ quartiles, because they distinguish the lower and upper quarters of the distribution (Titkova, 2002). Correspondence of initial scores of components of self-educational competence of future experts by levels of the development is presented in Table 2.

Table 2. Scaling of levels of formation of components of self-educational competence of future specialists

\begin{tabular}{lcccc}
\hline \multirow{2}{*}{ Component } & \multicolumn{4}{c}{ Level of development in initial points } \\
\cline { 2 - 5 } & Low $\left(<\mathrm{P}_{26}\right)$ & $\begin{array}{l}\text { Below } \\
\text { average } \\
\left(\mathrm{P}_{26}-\mathrm{P}_{50}\right)\end{array}$ & $\begin{array}{l}\text { Above } \\
\text { average } \\
\left(\mathrm{P}_{51}-\mathrm{P}_{75}\right)\end{array}$ & High $\left(>\mathrm{P}_{75}\right)$ \\
\hline Cognitive & $<=13.8$ & $(13.8 ;$ & $(17.5 ; 20.6)$ & $>20.6$ \\
Motivational & $0-24$ & $25-28$ & $29-31$ & $32-36$ \\
Activity & $0-19.5$ & $20-23$ & $23.5-27$ & $27.5-36$ \\
Communicative & $0-21$ & $21.5-25$ & $25.5-28.5$ & $29-36$
\end{tabular}

Data on the levels of the development of the components of self-educational competence of future specialists obtained at the summative stage of the experiment are shown in Table 3.

Table 3. Levels of the development of the components of self-educational competence of future specialists at the summative stage of the experiment

\begin{tabular}{|c|c|c|c|c|c|c|c|c|c|c|}
\hline \multirow{3}{*}{ Component } & \multirow{3}{*}{ Group } & \multirow{3}{*}{$\mathbf{N}$} & \multicolumn{8}{|c|}{$\begin{array}{l}\text { The level of the development of the components of } \\
\text { self-educational competence of future specialists }\end{array}$} \\
\hline & & & \multicolumn{2}{|c|}{ Low } & \multicolumn{2}{|c|}{ Below average } & \multicolumn{2}{|c|}{ Above average } & \multicolumn{2}{|c|}{ High } \\
\hline & & & $\mathrm{s}$ & $\%$ & $\mathrm{~s}$ & $\%$ & $\mathrm{~s}$ & $\%$ & $\mathrm{~s}$ & $\%$ \\
\hline \multirow[t]{2}{*}{ Cognitive } & EG & 61 & 19 & 31.1 & 14 & 23.0 & 15 & 24.6 & 13 & 21.3 \\
\hline & CG & 26 & 3 & 11.5 & 7 & 26.9 & 6 & 23.1 & 10 & 38.5 \\
\hline \multirow[t]{2}{*}{ Motivational } & EG & 61 & 14 & 23.0 & 21 & 34.4 & 12 & 19.7 & 14 & 23.0 \\
\hline & CG & 26 & 6 & 23.1 & 2 & 7.7 & 9 & 34.6 & 9 & 34.6 \\
\hline \multirow[t]{2}{*}{ Activity } & EG & 61 & 17 & 27.9 & 17 & 27.9 & 12 & 19.7 & 15 & 24.6 \\
\hline & CG & 26 & 4 & 15.4 & 4 & 15.4 & 9 & 34.6 & 9 & 34.6 \\
\hline \multirow[t]{2}{*}{ Communicative } & EG & 61 & 16 & 26.2 & 15 & 24.6 & 19 & 31.1 & 11 & 18.0 \\
\hline & CG & 26 & 5 & 19.2 & 4 & 15.4 & 6 & 23.1 & 11 & 42.3 \\
\hline
\end{tabular}

The objective of the formative stage of the experiment was to implement the pedagogical conditions for the development of self-educational competence of future specialists in the study of professional subjects. To achieve this objective, curriculum, tests, criterion-diagnostic system were developed. Work with students of experimental groups 
was carried out on the basis of the author's methodology. The results of the formative stage of the experiment allowed seeing the growth of the levels of the development of self-educational competence of future specialists by all components (Table 4).

Table 4. Levels of the development of the components of self-educational competence of future specialists at the formative stage of the experiment

\begin{tabular}{|c|c|c|c|c|c|c|c|c|c|c|}
\hline \multirow{3}{*}{ Component } & \multirow{3}{*}{ Group } & \multirow{3}{*}{$\mathbf{N}$} & \multicolumn{8}{|c|}{$\begin{array}{l}\text { The level of the development of the components of } \\
\text { self-educational competence of future specialists }\end{array}$} \\
\hline & & & \multicolumn{2}{|c|}{ Low } & \multicolumn{2}{|c|}{ Below average } & \multicolumn{2}{|c|}{ Above average } & \multicolumn{2}{|c|}{ High } \\
\hline & & & $\mathrm{s}$ & $\%$ & $\mathrm{~s}$ & $\%$ & $\mathrm{~s}$ & $\%$ & $\mathrm{~s}$ & $\%$ \\
\hline \multirow[t]{2}{*}{ Cognitive } & EG & 61 & 1 & 1.6 & 1 & 1.6 & 6 & 9.8 & 53 & 86.9 \\
\hline & CG & 26 & 3 & 11.5 & 7 & 26.9 & 4 & 15.4 & 12 & 46.2 \\
\hline \multirow[t]{2}{*}{ Motivational } & EG & 61 & 3 & 4.9 & 9 & 14.8 & 19 & 31.1 & 30 & 49.2 \\
\hline & CG & 26 & 7 & 26.9 & 8 & 30.8 & 7 & 26.9 & 4 & 15.4 \\
\hline \multirow[t]{2}{*}{ Activity } & EG & 61 & 5 & 8.2 & 10 & 16.4 & 12 & 19.7 & 34 & 55.7 \\
\hline & CG & 26 & 6 & 23.1 & 2 & 7.7 & 8 & 30.8 & 10 & 38.5 \\
\hline \multirow[t]{2}{*}{ Communicative } & EG & 61 & 3 & 4.9 & 11 & 18.0 & 13 & 21.3 & 34 & 55.7 \\
\hline & CG & 26 & 5 & 19.2 & 7 & 26.9 & 6 & 23.1 & 8 & 30.8 \\
\hline
\end{tabular}

Comparative analysis of the data obtained during the summative and formative stages of the experiment clearly demonstrates the dynamics of growth of the levels of the development of the components of self-educational competence of future specialists. Thus, the low level of the cognitive component of students' self-educational competence decreased in the experimental group by $20.5 \%$, while the level did not change in the control group. The high level of self-educational competence of students increased by $65.6 \%$ for cognitive, by $26.2 \%$ for motivational, by $31.1 \%$ for activity and by $37.7 \%$ for communicative components.

Thus, based on the results of comparing the levels of the development of components of self-educational competence of future specialists, we can conclude that the implementation of pedagogical conditions for the development of self-educational competence of future specialists in the study of professional subjects allows us to talk about positive dynamics.

The initial score of the level of self-educational competence is determined as the sum of the initial scores of diagnostic tests and questionnaires of the four components of self-educational competence. The initial results are standardized with the help of percentiles and the correspondence of initial scores with the levels of formation of self-educational competence is made (Table 5).

Table 5. Scaling of levels of the development of self-educational competence of future specialists

\section{Levels of the development in initial scores}

\begin{tabular}{cccc}
\hline Low $\left(<\mathrm{P}_{26}\right)$ & $\begin{array}{c}\text { Below average } \\
\left(\mathrm{P}_{26}-\mathrm{P}_{50}\right)\end{array}$ & $\begin{array}{c}\text { Above average } \\
\left(\mathrm{P}_{51}-\mathrm{P}_{75}\right)\end{array}$ & $\begin{array}{c}\text { High } \\
\left(>\mathrm{P}_{75}\right)\end{array}$ \\
\hline$<=82.75$ & $(82.75 ; 94.25)$ & $(94.25 ; 104.2)$ & $>104.2$
\end{tabular}

Comparison of the distribution of students (as a percentage) by levels of the development of self-educational competence at the summative (s) and formative (f) stages of the experiment is presented in Table 6.

Table 6. Comparison of the levels of formation of self-educational competence of future specialists at the summative and formative stages of the experiment

\section{The level of the development of self-educational competence of future} specialists

\begin{tabular}{|c|c|c|c|c|c|c|c|c|}
\hline \multirow[t]{2}{*}{ Group } & \multicolumn{2}{|c|}{ Low } & \multicolumn{2}{|c|}{ Below average } & \multicolumn{2}{|c|}{$\begin{array}{c}\text { Above } \\
\text { average }\end{array}$} & \multicolumn{2}{|c|}{ High } \\
\hline & $\mathrm{s}$ & $\mathrm{f}$ & $\mathrm{s}$ & $\mathrm{f}$ & $\mathrm{s}$ & $\mathrm{f}$ & $\mathrm{s}$ & $f$ \\
\hline EG & 29.5 & 3.3 & 26.2 & 4.9 & 26.2 & 11.5 & 18.0 & 80.3 \\
\hline $\mathrm{CG}$ & 15.4 & 19.2 & 15.4 & 11.5 & 26.9 & 23.1 & 42.3 & 46.2 \\
\hline
\end{tabular}


We see that the low level of self-educational competence of students decreased in the experimental group by $26.2 \%$, while in the control group the low level increased by $3.8 \%$. The high level of self-educational competence of students increased by $62.3 \%$ in the experimental group and only by $3.9 \%$ in the control group.

Let us test the assumption that there are statistically significant differences in the levels of self-educational competence in the control and experimental groups using Fisher's angular transformation. Fisher's test - $\varphi$ is used to compare two series of sample values on the frequency of any attribute (Kolomiets, 2018). The fact of the development of self-educational competence at a level above average and high is this attribute in our case. At the formative stage of the experiment, the presence of this attribute as a percentage is $91.8 \%$ for the experimental group, and $61.2 \%$ for the control.

According to the table of values of the angle $\varphi$ for different percentages (Ermolaev, 2003), we find $\varphi 1=2.561, \varphi 2=$ 1.965. The empirical value of $\varphi$-emp is calculated by formula 1 where $\mathrm{n} 1$ and $\mathrm{n} 2$ are the number of students in the experimental and control groups, respectively (Ermolaev, 2003). The critical values for the 5\% and 1\% significance levels have a fixed value and are $\varphi c r=1.64$ for $\mathrm{P} \leq 0.05 ; \varphi \mathrm{cr}=2.28$ for $\mathrm{P} \leq 0.01$.

The obtained value of $\varphi \mathrm{emp}=2.54471>2.28$, therefore, the differences between the groups are significant at the level of $1 \%$. In other words, at the formative stage of the experiment in the experimental group, the number of students with high and above average levels of self-educational competence is significantly higher than in the control group.

Similarly, you can compare the indicators of the control and experimental groups at the summative stage of the experiment. The presence of the attribute to be tested is $69.2 \%$ for the control group and $44.3 \%$ for the experimental group, respectively $\varphi 1=1,965 ; \varphi 2=1.457$ and $\varphi \mathrm{emp} \approx 2.17<2.28$. In other words, at the $1 \%$ level of significance, we can say that there are no differences between the control and experimental groups at the summative stage of the experiment.

For further analysis of the results of experimental work, we count the number of students who had changes at the formative stage of the experiment, i.e. the transition to a higher level compared to the summative stage. The results are given in Table 7, which shows that the effect in percentage is $77.0 \%$ for the experimental group and $23.1 \%$ for the control. Accordingly, $\varphi 1=2.141 ; \varphi 2=1.003$ and $\varphi \mathrm{emp} \approx 4.86$.

Table 7. Indicators of transition to a higher level in the control and experimental groups

\begin{tabular}{ccc}
\hline Group & $\begin{array}{c}\text { There is no } \\
\text { transition, \% }\end{array}$ & There is a transition, \% \\
\hline EG & 22.95 & 77.05 \\
CG & 76.92 & 23.08
\end{tabular}

The obtained value of $\varphi$ emp exceeds the corresponding critical value of $\varphi$ cr for the level of $1 \%$, therefore, the differences in the groups are significant at the level of $1 \%$. In other words, in the experimental group the number of transitions to a higher level is significantly higher than in the control group. In terms of statistical hypotheses, it can be argued that the null hypothesis $\mathrm{H}_{0}$ about similarity is rejected, and hypothesis $\mathrm{H}_{1}$ about differences is accepted at a high level of significance.

It can be concluded that students of control and experimental groups have significant differences due not to random factors, but to a natural reason - conducting research and experimental work on the implementation of pedagogical conditions for the development of self-educational competence of future specialists in the study of professional subjects. Statistical analysis of indicators of transition of students to a higher level of self-educational competence shows that the process of development of self-educational competence in students of the experimental group is more effective than in students of the control.

\section{Conclusions}

Summing up, we note that self-educational competence is manifested in the skills and abilities of self-improvement, skills of independent cognitive activity, which aimsat updating their own intellectual potential in accordance with cultural and professional needs of society, i.e. need for self-education. At the same time, self-educational competence forms on the basis of gaining experience of independent efforts and achievements in self-educational activities, developing one's own individual learning system, gradual transition from copying self-education patterns to developing one's own model, including self-education in lifestyle. The importance of the development of self-educational competence led us to identification of effective pedagogical conditions to ensure the effectiveness of this process during the study of professional subjects by students. 
Thus, the effectiveness of the system of the development of self-educational competence of future specialists in the study of professional subjects, which is based on pedagogical conditions that contribute to the development of self-educational competence of students, is confirmed by research and experimental work and can be recommended for practical implementation in HEIs.

The results of the research and experimental work showed that at the beginning of the experiment, students of the experimental and control groups were found to have approximately the same level of self-educational competence. By the end of the research, the level of self-educational competence of students in the experimental group increased significantly compared to the control group. The number of transitions to the next level of self-educational competence in the experimental group differs statistically significantly from this indicator in the control group, which confirms the effectiveness of the developed program of the experiment on implementation of the selected pedagogical conditions.

\section{Prospects for Further Scientific Research}

The performed research has made a certain contribution to the solution of the problem of the development of self-educational competence of future specialists in the study of professional subjects. At the same time, it does not exhaust all the variety of the stated problem. The study of such a complex phenomenon can be continued in the direction of finding innovative tools that contribute to the development of self-educational competence of students at different stages of education.

\section{References}

Adam, S. (2008). Learning outcomes current developments in Europe: Update on the issues and applications of learning outcomes associated with the Bologna process. Dublin, Ireland: Trinity College.

Adaryukova, L. (2017) Structural and functional model of self-educational competence of future software engineers. Current issues of humanitarian, of Technical and Natural Sciences: Collection of Reports and Abstracts of the II All-Ukrainian scientific-practical conference of students, graduate students and young scientists, 191-193. Dnipro, Ukraine: NBK.

Adubra, E. (2014). Fragmentation of teacher education: Responses from the teacher task force network. teacher education policy in Europe network. Retrieved from https://www.idi.hr/tepe2014/eadubra.pdf

Ahrens, A., Purvinis, O., Zaščerinska, J., \& Andreeva N. (2016). A model for simulation of study process optimization in rural areas. Rural Environment. Education. Personality. Proceedings of the International Scientific Conference, 9, 145-152.

Barbosa-Chacón, J. W., \& Castañeda-Peña, H. A. (2017). Integrating information literacy into university education: challenges and strategies for educational practice. Revista Espacios, 38(30), 28-35.

Batista, M. De F. M. C., \& Elliot, L. G. (2014). Avaliação da Autoeducação: Construção e Validação de Instrumento para o Professor Montessoriano [Self-education evaluation: Construction and validation of instrument for the montessorian teacher]. Meta: Avaliacao, 6(17), 176-198. http://doi.org/10.22347/2175-2753v6i17.134

Bilousova, L., \& Kiselyova, O. (2012). Competence of self-education in modern conditions. Information Technologies and Learning Tools, 1(27). Retrieved from http://www.journal.iitta.gov.ua https://doi.org/10.33407/itlt.v27i1.614

Carlson, D. (1998). Respondent: Self education —identity, self, and the new politics of education. In D. Carlson (Ed.), Power/knowledge/pedagogy: The meaning of democratic education in unsettling times, 191-200. New York, NY: Routledge. https://doi.org/10.4324/9780429498060-9

Ermolaev, O. Yu. (2003). Mathematical statistics for university psychologists. Moscow, Russia: MPSI.

Estriegana, R., Medina-Merodio, J.-A., \& Barchino, R. (2019). Analysis of competence acquisition in a flipped classroom approach. Computer Applications in Engineering Education, 27(1), 49-64. https://doi.org/10.1002/cae.22056

Gura, V. V., \& Lutseva, I. Yu. (2016). The role of the students' self-organization in the development of professionally significant competences. International Journal of Experimental Education, 11(2), 149-152.

Kolomiets, B. S. (2018). The roots of independent study in the USA. Comparative Professional Pedagogy, 8(4), 85-91. https://doi.org/10.2478/rpp-2018-0059

Levy, C. (2016). Education and self-education: staffing the early ILP. In C. Levy (Ed.), Socialism and the Intelligentsia 1880-1914, 135-210. London, UK: Routledge. https://doi.org/10.4324/9781315564128 
Maravilhas, S. (2015). Challenges for Education in the Information Society. In M. Khosrow-Pour (Ed.), Encyclopedia of Information Science and Technology, 4499-4506. Hershey, PA: IGI Global. http://doi.org/10.4018/978-1-4666-5888-2.ch441

Melnychuk, I. M. (2018). Formation of self-educational competence of future nursing specialists as a pedagogical problem. Scientific Bulletin of Uzhhorod National University: series: Pedagogy. Social work, 2(43), 168-172. https://doi.org/10.24144/2524-0609.2018.43.168-172

Nigmatullina, I. A., \& Boltakova, N. I. (2014). Lifelong learning as an actual strategy of higher professional education modernization in Russia (in case of speech therapy teachers' training). Life Science Journal, 11(11s), 30-33.

Oleynikova, O. N. (2009). The Bologna process and compatibility of curricula, diplomas and qualifications of higher education. Moscow State University Bulletin: Series "Psychological Sciences", 3, 13-25.

Sagitova, R. (2010). Formation of Self-Education Competence of university students in the context of a new educational paradigm. Kazan Pedagogical Journal, 4, 27-34.

Sagitova, R. R. (2011). Formation of self-education competence of higher school students in studying of the humanities disciplines [PhD thesis]. Institute of Education and Psychology of Professional Education, Kazan, Russia.

Sakhieva, R. G. (2015). Academic mobility of high school students: Concept, principles, structural components and stages of implementation. Journal of Sustainable Development, 8(3), 256-262. https://doi.org/10.5539/jsd.v8n3p256

Shazia, N. \& Muhammad, S. K. (2015). The impact of time management on the students' academic achievements. Journal of Literature, Languages and Linguistics, 11, 66-71.

Shkabarina, M. A. (2016). Educational potential of professional disciplines in the context of development of pedagogical creativity of future primary school teachers. International Scientific Journal "Scientific Review", 8(29). Retrieved from https://naukajournal.org/index.php/naukajournal/article/view/937/1076

Snam, R., Rusiman, M. S., Gan W. S., \& Arbin, N. (2018). The impact of time management on students' academic achievement. Journal of Physics: Conference Series, 995. https://doi.org/10.1088/1742-6596/995/1/012042

Sokolova, L. (2013). Self-educational competence of young researchers of pedagogical problems: Methodological aspect. Middle-East Journal of Scientific Research, 15(3), 339-343.

Stavitsky, O. N. (2013). The priority directions of professional education of a specialist' personality in the process of studies and educational work in a higher education institution. Nauka i studia, 33(101), 3-17.

Titkova, L.S. (2002). Psychodiagnostics. Vladivostok, Russia: Izdatel'stvo Dal'nevostochnogo universiteta.

Tregubova, T. M. (2013). Comparative study in the field of vocational education: major trends and challenges of adaptation. Kazan Pedagogical Journal, 3, 33-39.

Ualiyeva, N. T., Murzalinova, A. Zh., \& Kucher, T. P. (2016). Competence-oriented independent work of students in higher education institutions: Characteristics, content and organization. International Review of Management and Marketing, 6(S3), 146-155.

Vostiyanova, M. (2017). Influence of student's self-esteem on the effectiveness of education in the university. In S. A. Ivaschenko (Ed.), 73rd Student Scientific and Technical Conference of BSTU, 29-32. Minsk, Belarus: Belarusian National Technical University. 